\title{
Performance Analysis of Listed Companies in the UAE-Using DEA Malmquist Index Approach
}

\author{
Sudipa Majumdar ${ }^{1}$, Behrooz Asgari $^{2}$ \\ ${ }^{1}$ Middlesex University Dubai, Dubai, United Arab Emirates \\ ${ }^{2}$ Ritsumeikan Asia Pacific University, Kyushu, Japan \\ Email: s.majumdar@mdx.ac.ae,behrooz@apu.ac.jp
}

How to cite this paper: Majumdar, S. and Asgari, B. (2017) Performance Analysis of Listed Companies in the UAE-Using DEA Malmquist Index Approach. American Journal of Operations Research, 7, 133-151. https://doi.org/10.4236/ajor.2017.72010

Received: January 7, 2017

Accepted: March 28, 2017

Published: March 31, 2017

Copyright ( 92017 by authors and Scientific Research Publishing Inc. This work is licensed under the Creative Commons Attribution International License (CC BY 4.0).

http://creativecommons.org/licenses/by/4.0/

\begin{abstract}
Data Envelopment Analysis (DEA) is becoming an increasingly popular tool for assessing the relative performance of industries and companies. By applying DEA theory to the non-financial sector, the relative efficiency of 27 listed corporations in the United Arab Emirates (UAE) has been analyzed in this paper. The focus of the study has been on the impact of the financial crisis and the recovery thereafter. Further, the productivity change was decomposed into technical efficiency change and technological change by using the non-parametric Malmquist Productivity Index (MPI) over the period from 2007 to 2014. Based on Malmquist analysis, we find that the most efficient industries during the post-crisis period were food and beverages, telecommunication and pharmaceuticals. In contrast, the sectors that were adversely affected by the crisis were services, real estate, construction and cements. The break-up of the TFP indicated that the efficiency indices in the top performing industries were driven by technological improvements or frontier effects. The top-performing companies in the UAE during the 2007-14 period demonstrated innovation-led growth, aided by the use of better technology, investments in capital equipment, and adoption of new production processes.
\end{abstract}

\section{Keywords}

Performance, Total Factor Productivity, Data Envelopment Analysis, Malmquist Index, United Arab Emirates

\section{Introduction}

The global financial crisis during 2008-2009 has been considered as the most severe economic setback since the Great Depression of 1929-1933. Global GDP growth rate fell from $5.2 \%$ in 2007 to $3.2 \%$ in 2008 and to $-2.2 \%$ in 2009 along with dramatic falls in industrial production and global trade [1]. The crisis was 
accompanied by high unemployment rates along with a worldwide shortage of liquidity. It took a long time for most countries to recover from the recessionary pressures, with some countries facing challenges of unemployment, inflation, and high debt burdens upto 2013-14.

The UAE was adversely affected not only by the global recession and fall in the price of oil in 2009 but also due to the exodus of its expatriate population and the significant decline in tourism. The growth in real GDP in the UAE came down from $13 \%$ in 2006 to $1.3 \%$ in 2009 [1]. However, the aggressive expansionary strategy of the government helped the UAE to reverse the trend and the real GDP growth rate sprang back to $4.8 \%$ by 2013 , the highest amongst GCC countries and MENA region.

In the face of the economic slowdown, the UAE government began to pursue its diversification strategy into non-oil high-value manufacturing and service sectors. They adopted various industrial policies for sustainable development in the long-run and perhaps the most significant labor policy implemented in 2009 was the Wage Protection System (WPS) which was considered as a breakthrough in monitoring payments to unskilled construction workers. Another major effort to boost the manufacturing sector came through the trade agreements to increase domestic productivity and prepare the new, high-value industries to compete internationally. As a result, UAE's non-oil exports rose from AED 65.4 bn in 2009 to AED 148.2 bn in 2013 [2].

The present study looks into the impact of the global recession on the nonfinancial sectors in the UAE. We apply data envelopment analysis (DEA) techniques to analyze productivity growth for the publicly listed companies in the UAE. The study adopts the efficient frontier approach, by using Malmquist's [3] productivity index, based on DEA. The index breaks down changes into two mutually exclusive and exhaustive components: namely, changes in technical efficiency over time and shifts in technology over time.

The remainder of this paper is organized as follows. Section 2 introduces DEA and its extensions to the TFP growth through computation of the Malmquist Index. Section 3 describes the data and empirical findings. Section 4 discusses the sector-wise analysis of the empirical results. Section 5 provides conclusions and possible future directions.

\section{Data Envelopment Analysis}

In this paper, we use performance measures of decision-making units (DMUs) using data envelopment analysis (DEA) techniques. Estimation of frontier production and measures of efficiency began with Farrell [4]. He adopted an econometric approach and measured technical efficiency through actual deviations from an idealized frontier isoquant. Following him, there were several studies that looked into the production function estimation through different specifications of the function itself [5] [6] [7] because the choice of functional form brings a series of implications with respect to the shape of the implied isoquants and the concepts of efficiency frontiers. 
The econometric approach was subsequently taken over by the mathematical programming approach using Data Envelopment Analysis (DEA). DEA is an optimization method that uses linear programming for assessing the efficiency and productivity of DMUs in terms of a proportional change in inputs or outputs [8]. Technical efficiency is achieved with the maximization of outputs, from the use of a given set of inputs [9].

Suppose a decision making unit (DMU) generates the outputs $y_{i},(i=1,2, \cdots, t)$ from the inputs $x_{k},(k=1,2, \cdots, m)$, according to the weights $\left(v_{i}=1,2, \cdots, t ; w_{k}=1,2, \cdots, m\right)$ on the variables. To measure the efficiency of DMU “ $p$ ", Charnes, Cooper, and Rhodes [9] defined the fraction utilizing the total factor productivity rates as

$$
\frac{\sum_{i=1}^{t} v_{i} y_{i}}{\sum_{k=1}^{m} w_{k} x_{k}}
$$

The Data Envelopment Analysis program utilizes this rate of total factor productivity and maximizes the performance of the DMU " $p$ " relative to the performance of the other units. We can transform the fractional programming model into a linear programming model [8] [10] as follows.

$$
\operatorname{Max} v_{i} w_{k}\left(\frac{\sum_{i=1}^{t} v_{i} y_{i p}}{\sum_{k=1}^{m} w_{k} x_{k p}}\right)
$$

Subject to

$$
0 \leq\left(\frac{\sum_{i=1}^{t} v_{i} y_{i c}}{\sum_{k=1}^{m} w_{k} x_{k c}}\right) \leq 1 \text { and } v_{i}, w_{k}>0
$$

where $c=1,2, \cdots, p, \cdots, z$

$v_{i}=1,2, \cdots, t=$ weights of the inputs,

$w_{k}=1,2, \cdots, m=$ weights of the outputs.

When the constraint reaches a value of 1 , the DMU under measurement is said to be technically efficient and lies on the efficiency frontier that is composed of the set of efficient units. The observed data of inefficient units are said to be enveloped by the frontier. So, DEA measures the efficiency of each observation relative to the frontier that envelops all the observations. Solution of the linear programming model gives us an efficiency value of "p" DMU and the weights to reach this efficiency level. The concept of frontier is especially important for the analysis of efficiency, because we measure efficiency as the relative distance to the frontier. Firms that are technically inefficient operate at points in the interior of the frontier, while those that are technically efficient operate along the frontier.

Charnes, Cooper, and Rhodes [8] assumed constant returns-to-scale of the production function and Banker, Charnes, and Cooper [10] introduced the variable returns to scale (VRS) efficiency measurement model, allowing the breakdown of efficiency into technical and scale efficiencies in DEA. 


\section{Malmquist Productivity Index (MPI)}

The Malmquist Productivity Index (MPI) consists of distance functions representing multi-output and multi-input technologies based on the input and output quantities. The output distance function is used to consider a maximum proportional expansion of the output, given the inputs and the MPI measures the Total Factor productivity (TFP) growth change between two data points by calculating the ratio of the distances of each data point relative to a common technology.

The MPI represents Total Factor Productivity (TFP) growth of a DMU and reflects the increase or decrease in efficiency with progress or regress of the frontier technology over time under multiple inputs and multiple outputs framework. The TFP index is used to estimate the productivity change, which is decomposed into technical efficiency change and technological change.

The framework employed in the current study can be illustrated by Figure 1 following Fare et al. [11] [12], Hjalmarsson and Veiderpass [13], Berg, Førsund and Jansen [14], and Price and Weyman-Jones [15]. Figure 1 shows two observations on the input $x$ and output $y$ domain, at time $t$ and $t+1$. The objective is to measure the productivity growth between $t$ and $t+1$, in terms of the change from $z(t)$ to $z(t+1)$ and this is done by imposing a potential production frontier, as in Figure 1. The frontiers represent the efficient levels of output " $y$ " that can be produced from a given level of input " $x$ ". In order to make production technically efficient, the bundle $z(t)$ can be reduced by the horizontal distance ratio (ON/OS). Again, in order for $\mathrm{z}(t+1)$ to be efficient in period $(t+$ $1)$, it must be reduced by the horizontal distance (OP/OQ).

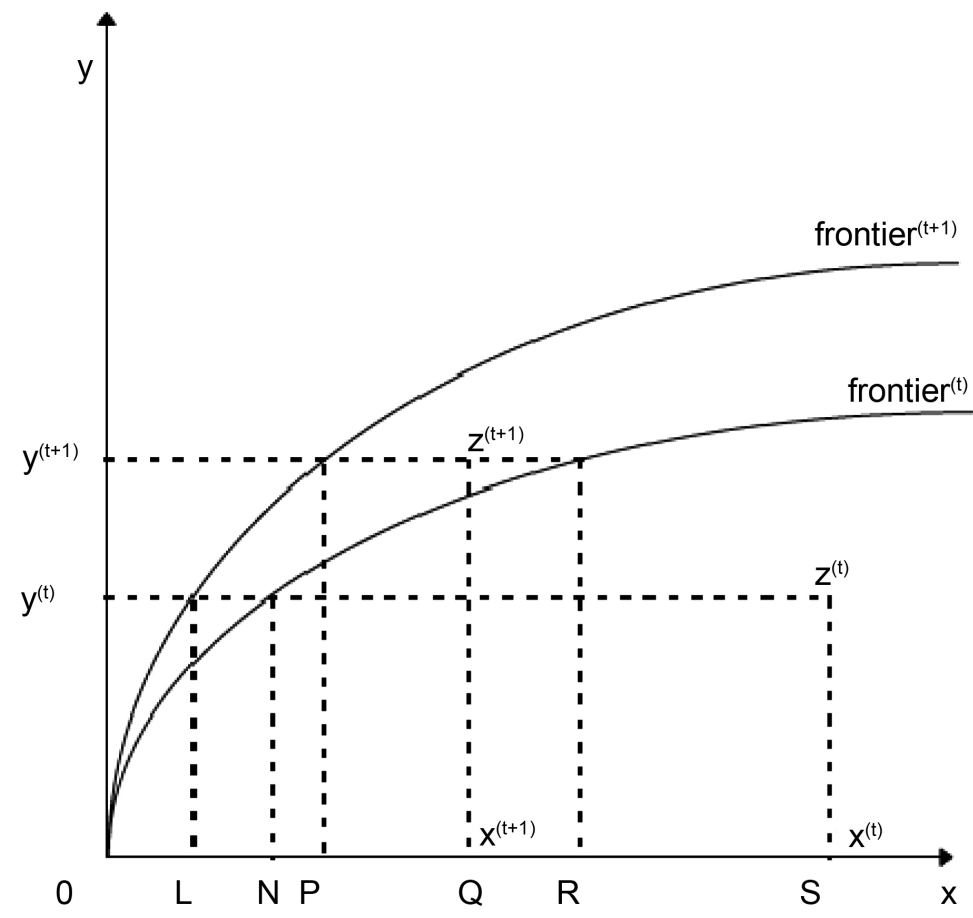

Figure 1. Decomposition of TFP growth. 
Malmquist [3] based his index on the output distance function and Caves et al. [16] extended the measure by a multi-input, multi-output index. Färe et al. [11] measured the frontier shift as the relative distance between the frontiers at $t$ and $t+1$ and further measured the MPI as a geometric mean of such indices which was factorized into the product of technical efficiency change and technological change. The relative movement of a particular DMU over time will depend on both its position relative to the corresponding frontier (technical efficiency) and the position of the frontier itself (technological change).

In order to calculate these indices it is necessary to solve several sets of linear programming problems. If there are $\mathrm{N}$ companies and each uses varying amounts of $\mathrm{K}$ different inputs to produce $M$ different outputs, then we would have $(K \times N)$ input matrix and $(M \times N)$ output matrix. This would help us construct a nonparametric envelopment frontier over the data points such that all observed points lie on or below the production frontier. The input distance functions that have been used to construct the Malmquist indices in this paper are the reciprocals of Farrell's [14] input-orientated technical efficiency measures, following the DEA model of Charnes, Cooper and Rhodes [8].

The DEA measure of efficiency is relative in that it is calculated in relation to all other DMUs in the sample. The efficiency score for each company is compared with technologies from the same time period and then compared to technologies from different time periods. The Malmquist Productivity Index constructs an efficient frontier based on the data and each company is then compared to that frontier. The closeness of a company to the frontier is "catching up" while the shifting of the frontier itself is the "innovation". The product of these two components yields a frontier version of productivity change, which is the Malmquist TFP Index.

The Malmquist productivity index measures the total factor productivity change between two data points over time, by calculating the ratio of distances of each data points relative to a common technology. Färe et al. [12] define the change of productivity between period $\mathrm{t}$ and $t+1$ as

$$
M_{t+1}^{t}\left(y_{t+1}, y_{t}, x_{t}\right)=\left[\frac{d_{t}\left(y_{t+1}, x_{t+1}\right)}{d_{t}\left(y_{t}, x_{t}\right)} * \frac{d_{t+1}\left(y_{t+1}, x_{t+1}\right)}{d_{t+1}\left(y_{t}, x_{t}\right)}\right]^{1 / 2}
$$

where $M$ is the Malmquist productivity index in time $t+1$ using the " $t+1$ " technology relative to the production in time $t$ using the " $t$ " technology. This equation represents the Malmquist productivity or TFP growth between the time period $\mathrm{t}$ and $t+1$ as a geometric mean of the efficiency measures of each period. Moreover, the efficiency measure in a particular time period is given by the distance function relative to the frontier technology. A value greater than one will indicate a positive TFP growth from period to period $t+1$ while a value lesser than one will indicate a decrease in TFP growth relative to the previous year. We now write the Malmquist Productivity Index as

$$
M_{t+1}^{t}\left(y_{t+1}, y_{t}, x_{t}\right)=\frac{d_{t+1}\left(y_{t+1}, x_{t+1}\right)}{d_{t}\left(y_{t}, x_{t}\right)} *\left[\frac{d_{t}\left(y_{t+1}, x_{t+1}\right)}{d_{t+1}\left(y_{t+1}, x_{t+1}\right)} * \frac{d_{t}\left(y_{t}, x_{t}\right)}{d_{t+1}\left(y_{t}, x_{t}\right)}\right]^{1 / 2}
$$


where the first term defines changes in technical efficiency (E) from period $t$ and $t+1$ and the second indicates changes in technology (P), i.e., a shift in the frontier from period $\mathrm{t}$ to period $t+1$. So, we now have our equations as follows:

Malmquist (TFP) Index $=$ Technical Efficiency Change $*$ Technological Change

$$
\begin{aligned}
& \text { (catching up effect) (innovation effect) } \\
& M=E^{*} P
\end{aligned}
$$

If an organization fails to achieve an output combination on its production possibility frontier, and fails beneath this frontier, it can be said to be "technologically inefficient". Over time the level of output an organization is capable of producing will increase due to technological changes that affect the ability to optimally combine inputs and outputs. These technological changes cause the production possibility frontier to shift upward, as more outputs are obtainable from the same level of inputs. Thus, for any organization in an industry, productivity improvements over time may be either technical efficiency improvements (catching up with their own frontier) or technological improvements (the frontier is shifting up over time) or both.

Further, the variable returns to scale (VRS) are incorporated by introducing convexity constraints into the linear program. Using these models, and the Fare et al. [12] approach, it is thus possible to provide four efficiency/productivity indices for each firm and a measure of technical progress over time. These are:

$1)$ technical efficiency change ( $E$ ) (relative to a CRS technology);

2) technological change $(P)$;

3) pure technical efficiency change ( $P T)$ (relative to a VRS technology);

4) scale efficiency change $(S)$; and

5) total factor productivity $(M)$.

We can then calculate scale efficiency from the technical efficiency measures for VRS technologies in the following way:

Technical Efficiency Index $x_{\mathrm{VRS}}=$ Technical Efficiency Index $\mathrm{VRS}_{\mathrm{VRS}} \times$ Scale Efficiency Index

Fare et al. [12] decomposed the catching up effect into "pure" technical efficiency change and "scale" efficiency change. That is,

Technical Efficiency $=$ Pure Technical Efficiency $\times$ Scale Efficiency

Change Index Change Index Change Index

$$
E=P T * S
$$

If $M>1$, then productivity gains occur, and if $M<1$, productivity losses occur. Technical efficiency increases (decreases) if and only if $\mathrm{E}$ is greater (less) than one and technological progress (regress) has occurred if $\mathrm{P}$ is greater (less) than one. An assessment can also be made of the major sources of productivity gains/losses by comparing the values of $\mathrm{E}$ and $\mathrm{P}$. If $E>P$ then productivity gains are largely the result of improvements in efficiency, whereas if $E<P$ productivity gains are primarily the result of technological progress. Moreover, if $P T>S$ then the major source of efficiency change is improvement in pure technical efficiency, whereas if $P T<S$ the major source of efficiency is an improvement in scale 
efficiency. Further details on the interpretation of these indices may be found in Charnes et al. [17].

\section{Literature Review}

The first empirical application of the decomposition of productivity changes into technical and technological changes was used to measure hospital productivity in Sweden by Nishimizu and Page [18]. The enhanced decomposition model to identify between pure technical efficiency and scale efficiency was carried out by Färe et al. [12] while analyzing the productivity growth in 17 OECD countries the United States was found to consistently shift the frontier driven by technical change but the productivity growth in Japan was above average mainly due to technological changes. Following this there have been numerous empirical studies that followed this methodology to measure productivity changes at the country level; industry level as well as firm level. Most of the studies have concentrated on the financial sector, especially banking, and the literature is quite scant in the non-financial sector. Since the present study looks into the non-financial sector of the UAE, this section will concentrate of a review of existing literature relating to the non-financial industries.

Some of the countries that have been included in the research for performance evaluation of non-financial sector in the Middle Eastern region include Israel by Friedman and Stern [19]; Jordan by Shammari [20] and Turkey by Ulucan [21]. A world-wide study of Fortune 500 companies was done by Zhu [22] who carried out separate profitability and marketability analyses using DEA. Other studies relating to the manufacturing sector include Bayyurt and Duzu [23] whose study on China and Turkey concluded that Chinese manufacturing firms to be highly efficient as compared to the Turkish firms on an average. Tahir and Memon [24] studied manufacturing companies in Pakistan and found only one company (out of 14) to be technically efficient while the average overall technical efficiency varied from 0.64 to 0.99 .

Company level studies have been found for the automobile industry and a comparison between Toyota, Nissan, and Ford by Cusumano [25] over the time period 1960-1983 showed significant increases in labor productivity by Toyota and Nissan. Friedlander et al. [26] studied US automakers for the period 19551979 and found a decreasing productivity growth for Chrysler. In fact a comparative trend showed that the big three Japanese producers (Toyota, Nissan, and Mazda) had achieved higher labor productivity during the 1970s than their US Big three counterparts Lieberman [27].

DEA approach has also been applied for various other industries across the globe. Performance evaluation of the pharmaceutical sector using the non-parametric DEA approach has been carried out in India and output efficiency of firms has been studied by Majumder [9], Saranga, and Phani [28] and Mazumdar and Rajeev [27]. Keramidou et al. [29] revealed inefficiencies arising from mismanagement and excess usage of capital in the when studying the Greek meat products industry. Studies relating to efficiency of telecommunication in- 
dustry are also sparse. Sueyoshi [30] looked into the scale economies before and after privatization of Nippon Telegraph \& Telephone while Facanha and Resende [31] used DEA calculated the relative efficiency of the telecom sector in Brazil. Cooper, Park, and Yu [32] applied the model to a Korean telecommunication company while Uri [33] [34] used DEA to investigate the effect of incentive regulation in the US telecommunication industry.

The performance evaluation of small and medium enterprises has also been of particular interest, especially in the Far Eastern countries. Batra and Tan [35] found a positive relation between technical efficiency and company size where efficiency was driven by factors like training of workers, investments in new technology, automation. Market liberalization was the cause of technical efficiency and improved performance in the steel industry of Taiwan but led to widespread inefficiencies in the retail sector [36]. The literature on DEA applications to large scale manufacturing can be found for Asian countries, relating to the 1990s and early 2000s. During this time period most of the large scale units belonged to the public sector which were characterized by low performance and operating inefficiencies. The large scale manufacturing units in Pakistan showed only marginal improvements in operations during the 1990s and early 2000s [37]. Singh [38] found the performance of the private sector sugar mills in North India to be better performers as compared to cooperative and government sectors. Higher inefficiencies of public sector firms were also found for pharmaceutical firms in India [9]. For the state owned Electric utilities in India, only 24 percent of the firms were efficient [39].

Therefore, we find that the non-parametric productivity analyses have been applied to various sectors but most have concentrated on one particular segment of the country. Firm-level trend analysis has been few and sparse. More importantly, all research relating to the UAE studied the financial companies within the banking and the insurance sectors. Our study makes an important contribution to the existing literature by looking into the firm level trend analysis of non-manufacturing units in the UAE.

\section{Research Methodology}

We evaluated the overall efficiency of 27 firms in the United Arab Emirates by using firm-level information for the years 2007 to 2014 for companies that were listed on the Abu Dhabi Securities Exchange and the Dubai Financial Market. We have taken a balanced panel and the data was collected from individual audited annual reports from companies for each year. Table 1 gives the classification of the data in terms of the industry.

Our study included two outputs and three inputs. Ideally, the analysis of efficiency should include the physical volume of outputs and inputs. However, in the absence of data following standard practice [40], we have used values of outputs and inputs according to the financial statements of the companies.

In this study there are 27 DMUs with three inputs: Labour (measured in terms of the wages and salaries of workers); Capital (measured in terms of the net book 
Table 1. Classification of firms, according to industry.

\begin{tabular}{cc}
\hline Industry & Number of Firms \\
\hline Real Estate\& Construction & 7 \\
Cements & 5 \\
Manufacturing & 4 \\
Services & 4 \\
Food and Beverages & 3 \\
Telecommunications & 2 \\
Pharmaceuticals & 2 \\
Total Number of Firms & $\mathbf{2 7}$ \\
\hline
\end{tabular}

value of the property, plant, equipment under the non-current assets of the Balance Sheet); and Materials (measure in terms of the cost of goods sold in the income Statement). The two outputs were revenue (measured in terms of sales) and earnings per share (EPS). The time duration for the analysis is eight years, from 2007 to 2014. Table 2 and Table 3 give the average values and descriptive statistics of the inputs and the outputs of each industrial sector, for the 216 firm-years between 2007 and 2014. In order to bring the variables in real terms, each variable was deflated using the Consumer Price Index (CPI) general index which is published by the Dubai Statistics Centre and the National Bureau of Statistics, United Arab Emirates. The classification of the firms according to industry was done according to the primary listing on the Zawya Database of companies for the UAE.

The Malmquist productivity approach based on data envelopment analysis (DEA) was used to identify the major source of productivity growth where the DEA allows for the estimation of Total Factor Productivity (TFP) as a Malmquist Productivity Index (MPI). The MPI was decomposed to the "frontier" and "catching up" effects which was further decomposed to pure technical efficiency change and scale efficiency change. Table 4 below summarizes the mean efficiency growth rates indices for each industrial sector. Based on Malmquist analysis, we find that the most efficient industries during the 2007-2014 period were food, telecommunication and pharmaceuticals (Table 4) which had TFP change of 1 or more. In contrast, the sectors that were adversely affected by the 2008-09 crisis and found it difficult to recover during this period were services, real estate, construction and cements (Figure 2).

Table 5 gives the break-up of the TFP Malmquist Index at the sectoral level which indicates that within the most efficiency industries in the UAE, the productivity was driven by technology and innovation (frontier effect), through use of better technology and capital equipment. In contrast, we do not find "catching up" effect in any of the industries during this period except for Food and Beverages. The company-wise break-up in Table 6 shows that the highest MPI were shown by Emirates Integrated Telecom; Dubai Refreshments; Emaar; Foodco and Gulf Pharmaceuticals and once again their efficiency was driven by tech- 
Table 2. Average values of variables, according to industry.

\begin{tabular}{cccccc}
\hline & \multicolumn{3}{c}{ Inputs } & Outputs \\
\hline Industry & $\begin{array}{c}\text { Labor } \\
\text { (AED) }\end{array}$ & Capital (AED) & $\begin{array}{c}\text { Materials } \\
\text { (AED) }\end{array}$ & $\begin{array}{c}\text { Revenue } \\
\text { (AED) }\end{array}$ & EPS \\
\hline Cements & 191,059 & $5,710,086$ & $3,564,858$ & $4,217,946$ & 0.14 \\
Food \& & 692,192 & $2,282,533$ & $4,403,920$ & $5,949,558$ & 0.48 \\
Beverages & 856,358 & $7,288,552$ & $7,948,016$ & $10,508,025$ & 0.17 \\
Manufacturing & $1,138,959$ & $7,542,615$ & $2,764,029$ & $5,843,692$ & 0.19 \\
Pharmaceuticals & $2,383,352$ & $19,241,503$ & $31,278,697$ & $43,634,411$ & 0.39 \\
Real Estate & 727,671 & $26,146,715$ & $4,874,580$ & $7,115,163$ & 0.54 \\
Services & $22,187,961$ & $128,293,411$ & $88,278,060$ & $174,919,808$ & 0.66 \\
Telecom & & & & & \\
\hline
\end{tabular}

Table 3. Descriptive statistics of inputs and outputs.

\begin{tabular}{cccccc}
\hline & \multicolumn{3}{c}{ Inputs } & Outputs \\
\hline & Labor (AED) & Capital (AED) & $\begin{array}{c}\text { Materials } \\
\text { (AED) }\end{array}$ & $\begin{array}{c}\text { Revenue } \\
\text { (AED) }\end{array}$ & EPS \\
\hline Mean & $2,692,788$ & $21,314,877$ & $17,902,277$ & $28,755,520$ & 0.35 \\
Median & 738,418 & $6,772,662$ & $5,511,522$ & $8,553,126$ & 0.24 \\
Maximum & $50,943,429$ & $380,442,006$ & $263,427,532$ & $403,565,665$ & 2.97 \\
Minimum & 22,982 & 62,010 & 117,991 & 104,062 & $(4.39)$ \\
StdDev & $7,187,276$ & $43,985,495$ & $33,876,106$ & $57,941,466$ & 0.55 \\
Skewness & 4.702 & 4.563 & 4.184 & 3.893 & $(1.616)$ \\
Kurtosis & 22.75 & 27.11 & 21.18 & 16.77 & 27.64 \\
\hline
\end{tabular}

Table 4. Mean Malmquist Index (TFP) for each industrial sector.

\begin{tabular}{cc}
\hline Industry & Malmquist Index \\
\hline Food and Beverages & 1.02 \\
Telecommunication & 1.01 \\
Pharmaceuticals & 0.99 \\
Manufacturing & 0.97 \\
Services & 0.94 \\
Real Estate \& Construction & 0.94 \\
Cements & 0.92 \\
\hline
\end{tabular}

nological change, improvements through innovation and adoption of new technologies (Table 7).

\section{Sectoral Findings and Analyses}

\subsection{Food and Beverages}

Figure 2 indicates that the growth in the Food industry in UAE was steady and stable, despite the difficult international environment. Food faces inelastic demand and is characterized by a high degree of resilience, which helped to maintain 
Table 5. Ranking of companies according to Malmquist Index (TFP).

\begin{tabular}{cccc}
\hline Companies Above Average & \multicolumn{2}{c}{ Companies Below Average } \\
\hline Emirates Integrated Telecom & 1.094 & Gulf Medical Projects & 0.965 \\
Dubai Refreshments & 1.039 & RAK Cements & 0.960 \\
Emaar & 1.023 & Arkan Building Materials & 0.953 \\
Foodco & 1.015 & Aldar Properties & 0.950 \\
Gulf Pharmaceuticals & 1.014 & Fujairah Building Industries & 0.949 \\
Abu Dhabi Shipbuilding Co & 0.997 & Sharjah Cements & 0.943 \\
Agthia Group & 0.996 & Abu Dhabi National Hotels & 0.940 \\
Tabreed & 0.991 & Etisalat & 0.931 \\
RAK Ceramics & 0.985 & National Corp for Tourism & 0.924 \\
Union Properties & 0.981 & Emirates Driving Company & 0.909 \\
Drake and Scull International & 0.977 & Arabtec & 0.906 \\
Gulf Cement Company & 0.972 & National Marine Dredging & 0.898 \\
& & Fujairah Cement Company & 0.850 \\
& & Umm-al Quwain Cements & 0.847 \\
MEAN & $\mathbf{0 . 9 7 0}$ & GGICO & 0.846 \\
\hline
\end{tabular}

Table 6. Efficiency break-up for most efficient companies.

\begin{tabular}{cccccc}
\hline Companies & $\begin{array}{c}\text { Malmquist } \\
\text { Index }\end{array}$ & $\begin{array}{c}\text { Technological } \\
\text { Efficiency }\end{array}$ & $\begin{array}{c}\text { Technical } \\
\text { Efficiency }\end{array}$ & $\begin{array}{c}\text { Pure Tech } \\
\text { Efficiency }\end{array}$ & $\begin{array}{c}\text { Scale } \\
\text { Efficiency }\end{array}$ \\
\hline M & $\mathrm{P}$ & $\mathrm{E}$ & $\mathrm{PT}$ & $\mathrm{S}$ \\
\hline $\begin{array}{c}\text { Emirates Integrated } \\
\text { Telecom }\end{array}$ & 1.094 & 1.065 & 1.027 & 1.025 & 1.002 \\
Dubai Refreshments & 1.039 & 1.044 & 0.995 & 1.017 & 0.979 \\
Emaar & 1.023 & 1.030 & 0.993 & 1 & 0.993 \\
Foodco & 1.015 & 1.015 & 1 & 1 & 1 \\
Gulf Pharmaceuticals & 1.014 & 1.045 & 0.970 & 0.971 & 0.999 \\
\hline
\end{tabular}

a stable demand. After the crisis, since 2011, the UAE Government began to encourage domestic food production to reduce reliance on imports and to drive expansion of local providers. The support from the Government was coupled with a renewed influx of expatriate population, rising affluence, hectic lifestyles, and renewed growth in tourism. During 2012-13, the Food Security Centre of Abu Dhabi undertook initiatives to encourage new investments and set up special zones such as the Khalifa Industrial Zone Abu Dhabi (KIZAD) and Dubai Investments Park (DIP) with modern infrastructure, advanced warehousing facilities and excellent transportation network. So, demand for food products enjoyed an unprecedented growth both from the domestic as well as tourist population along with the support from the Government to step up the indigenous supplies. This resulted in a soaring Malmquist Productivity Index for the Foods and Beverages industry from 2012, as can be seen in Figure 2.

There are three listed companies in the Foods and Beverages sector in the 
Table 7. Technological and technical efficiency improvements.

\begin{tabular}{|c|c|}
\hline $\begin{array}{l}\text { Improvements in both Technological and } \\
\text { Technical Efficiency }\end{array}$ & $\begin{array}{c}\text { Emirates Integrated Telecom } \\
\text { Foodco }\end{array}$ \\
\hline $\begin{array}{l}\text { Improvements in Technological change but } \\
\text { decline in Technical Efficiency }\end{array}$ & $\begin{array}{c}\text { Abu Dhabi Shipbuilding Co } \\
\text { Agthia Group } \\
\text { Aldar Properties } \\
\text { Arkan Building Materials } \\
\text { Drake and Scull International } \\
\text { Dubai Refreshments } \\
\text { Emaar } \\
\text { Etisalat } \\
\text { Fujairah Building Industries } \\
\text { Gulf Cement Company } \\
\text { Gulf Medical Projects } \\
\text { Gulf Pharmaceuticals } \\
\text { RAK Ceramics } \\
\text { Sharjah Cements } \\
\text { Tabreed }\end{array}$ \\
\hline $\begin{array}{l}\text { Improvements in Technical Efficiency but } \\
\text { decline in Technological change }\end{array}$ & $\begin{array}{c}\text { Emirates Driving Company } \\
\text { Fujairah Cement Company } \\
\text { Union Properties }\end{array}$ \\
\hline $\begin{array}{l}\text { Decline in both Technological and Technical } \\
\text { Efficiency }\end{array}$ & $\begin{array}{c}\text { Abu Dhabi National Hotels } \\
\text { Arabtec } \\
\text { GGICO } \\
\text { National Corp for Tourism } \\
\text { National Marine Dredging } \\
\text { RAK Cements } \\
\text { Umm-al Quwain Cements }\end{array}$ \\
\hline
\end{tabular}

UAE and two of them were amongst the highest TFP scorers during the 20072014 period. Table 5 shows that Foods and Beverages sector showed the highest overall TFP score with Dubai Refreshments and Foodco being the two top performers (Table 6). All the three listed food companies-Foodco, Dubai Refreshments and Agthia-showed positive technological change during the 2007-2014 period. Dubai Refreshments leads the carbonated soft drinks sector and made huge investments in capital projects for building new capabilities. The company's relocation to its new state of the art distribution facility at the Dubai Investment Park enhanced their production capacity and operational efficiency. Investments in 2013 also went up with Agthia's new water bottling line and a new mega distribution center along with the completion of their research and development laboratory.

Although the food and beverages sector showed the highest level of efficiency, it was driven by technological advances without any commensurate efficiency improvements in the internal management of the firms. Foodco was the only company that showed a combination of technological and technical efficiency. Foodco launched several incentives and training programs; introduced effective quality check system along with proper inventory controls. Foodco also established a new Commodities Division in 2012 with a dedicated sales team, followed by expansion of their facilities in 2013 at the new premises in Mafraq. 


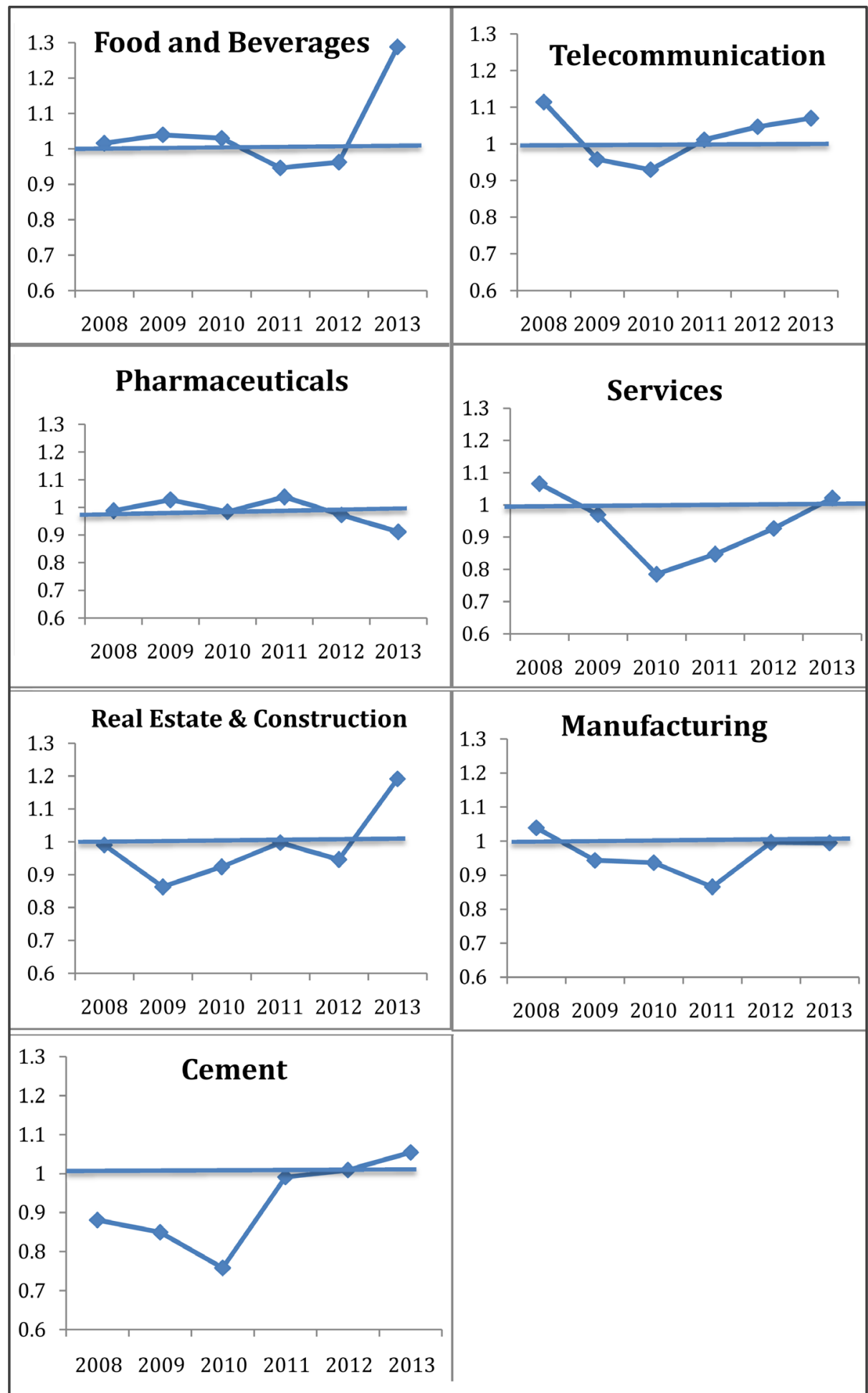

Figure 2. Malmquist productivity index over time for each sector.

However, such human resource incentives of Foodco to improve internal technical expertise of the company were not evident across the industry. Despite the technological improvements and capital expansions, both Agthia and Dubai Refreshments showed decline in technical efficiency, implying positive investments without a balance of the new inputs versus outputs. 


\subsection{Telecommunications}

The UAE telecommunications sector is among the strongest and most advanced in the world and was served by a monopolist provider, Emirates Telecommunications Corporation (Etisalat). Competition in the sector started in 2007 when Emirates Integrated Telecom (Du) launched its mobile network services ending 30 years of monopoly by Etisalat. Soon after the entry of $\mathrm{Du}$, the financial crisis hit the sector resulting in 20\% decrease in fixed lines during 2009-10, leading to the downturn in 2008-2010 (Figure 2). Although voice services have been on a downtrend since 2009, other technologically advanced services have increased manifold in the last five years. The Telecommunications Regulatory Authority (TRA) made significant leaps in investments in services and infrastructure since 2010, like the electronic federal network (FedNET) to provide high-speed connectivity and a secure electronic hosting service. The new "bitstream" technology was also introduced in 2010 when Emirates Integrated Telecom was given access to Etisalat's network. Both Etisalat and Emirates Integrated Telecom showed positive technological change (Table 7) since innovation was the main focus of the industry.

Emirates Integrated Telecom also showed a positive technical efficiency change (catching up effect) as the company successfully promoted various programmes among employees which included Employee Wellness scheme, Personal Action Plans, graduate training programmes and a strong Emiratisation drive. However, the technical efficiency of Etisalat began to suffer as the company lost its monopoly in the sector and also lost its coverage of the lucrative areas in Dubai such as Dubai Marina and TECOM.

\subsection{Pharmaceuticals}

Healthcare has been a top priority for the government and the sector received strong incentives to encourage local manufacturer through favorable pricing structures of generics; reduction of imports; policies relating to mandatory health insurance. The pharmaceutical industry remained strong and stable during the recession years owing to mandatory health insurance and the growth of regional medical tourism including huge investments in the Dubai Healthcare City as well as the Dubai Biotechnology \& Research Park. The UAE developed into one of the most advanced countries in terms of its healthcare services through its strategies of increasing longevity, eradication of all types of diseases, and an effective mechanism of early detection system of chronic diseases. The Ministry of Health continued to develop primary healthcare services through the establishment of an extended network of world class clinics all over the country.

Gulf Pharmaceuticals mainly drove the growth of the industry through its entry into the high-technology field of biotech as it began production of bulk human insulin crystals. Despite the recessionary pressures, the company continued to launch new products to diversify its market presence and successfully began off-shore investments in Saudi Arabia, Ethiopia and Algeria. However, the major hurdle for local manufacturers was the capital intensive nature of operations and 
the shortage of knowledge and skilled manpower which led to the decline in the technical efficiency of the sector. Further, the companies are highly dependent on imports of equipment, ingredients, and medicines for end use which makes the industry vulnerable to foreign exchange fluctuations, leading to a fall in the Malmquist index since 2011.

\subsection{Services, Construction and Cements}

Significant decline in tourism, widespread closures and exodus of expatriates from the UAE led to the downtrend in these sectors. The services industry recovered the quickest owing to international conferences/exhibitions by multinational companies; leisure tourism from the emerging Asian economies; niche markets like spa tourism, halal tourism, cultural tourism and budget tourism.

The sectors that were adversely affected by the 2008-09 crisis were real estate, construction and cements. The slowdown in the Dubai property market during the crisis years was caused by a phenomenon known as Dutch Disease-a situation in which capital outflows caused a dramatic fall in the profitability of the booming real estate sector and thus causing resources (labor and capital) to move out of this sector. This led to the decline in both technical efficiency measures for almost all (6 out of 7) real estate companies.

With regards to changes in scale efficiency, the values for 15 out of 27 companies were approximately 1 which showed that these companies were operating at optimum scale and experiencing constant returns to scale.

\section{Conclusions}

Performance measurement is crucial for any firm in any sector, not only for determining its own efficiency and achievement but also by benchmarking itself in comparison with its peers. This research paper uses the Malmquist productivity index which has been widely used across the globe, to evaluate the productivity trend over time, for multi-inputs and multi-outputs production units. The Total Factor Productivity growth has been measured over the period 2007-2014 for the non-manufacturing production units in the UAE and the efficiency trends have been studied with respect to the frontier technology. The TFP index has been further decomposed into technical efficiency change and technological change. Technical efficiency (catching up effect) shows a movement towards the efficient frontier of production while technological change (frontier shirt) implies innovation and investment. Based on the findings above, several useful managerial insights and implications have been discussed in the context of the non-financial sector of the UAE.

Our results are extremely encouraging for the period of the financial crisis and the recovery thereafter (2007-2014), as we found 17 out of 27 companies experienced technological improvement through investments in infrastructure, expansion of facilities, adoption of new technologies and/or their on research and development. However it is a matter of concern that only 5 out of 27 companies show a positive technical efficiency change-this implies that although there have 
been positive investments and government support in all the sectors to encourage expansions, the industries shows lack of proper balance of the new inputs versus outputs.

Pharmaceuticals and Food sectors in the UAE showed a high degree of resilience during the crisis years and did not suffer with the deterioration in the economic conditions of the country. Foods and services sectors were quick to display high growth from 2011 with inflow of expatriates and tourists into the UAE. The Government also enhanced the recovery by encouraging huge investments in facilities and infrastructure in Abu Dhabi, Sharjah and Dubai. Although technological efficiency was high, there was an overall decline in technical efficiency since the improvements in technology were not supported by efficiencies in internal management of the companies. As a result, we do not find "catching up" effect in any of the industries during this period except for Food and Beverages.

This paper identifies the efficiency indices-total factor productivity along with technical and technological efficient change indices-the application of which has been very sparse not only in the UAE but also in the overall application of DEA models with Malmquist index. Further, most of the studies on non-parametric efficiency measures have been applied to the financial sector and there are a host of studies pertaining to banks, insurance companies, non-banking financial institutions, financial cooperative societies etc. The application to the non-financial firms is scant. More importantly, there have been no studies that have looked into the recovery period in the last five years. This is particularly important for the UAE, since the country was one of the worst hit during the financial crisis of 2008 and has made a remarkable comeback. It was particularly interesting to note the efficiency measure of the various industries in order to trace the recovery and identify the factors that helped to improve the efficiency measures. Therefore, this study makes a major contribution to the existing literature of efficiency measures using non-parametric approach.

There are some limitations of this research since the DEA approach determines only relative efficiency and also does not identify the factors that give rise to inefficiency. So, we could only highlight those units in which inefficiency exists and those that require attention and the inefficiency index is only relative to the most efficient frontier. More importantly, we would be able to gain more insight by incorporating a model of structural change within this framework-so that we can identify the difference in trends during the crisis years (2007-2010) and the recovery period (2010-2014).

\section{References}

[1] United Arab Emirates (2009) National Bureau of Statistics Report.

[2] United Arab Emirates (2014) The Annual Economic Report.

[3] Malmquist, S. (1953) Index Numbers and Indifference Surfaces. Trabajos de Estadistica, 4, 209-242. https://doi.org/10.1007/bf03006863

[4] Farrell, M.J. (1957) The Measurement of Productive Efficiency. Journal of the Royal 
Statistical Society, 120, 253-290. https://doi.org/10.2307/2343100

[5] Afriat, S. (1972) Efficiency Estimation of Production Functions. International Economic Review, 13, 568-598. https://doi.org/10.2307/2525845

[6] Aigner, D. and Chu, S. (1968) On Estimating the Industry Production Function. American Economic Review, 58, 826-839.

[7] Timmer, P. (1971) Using a Probabilistic Frontier Production Function to Measure Technical Efficiency. Journal of Political Economy, 79, 776-794. https://doi.org/10.1086/259787

[8] Charnes, A., Cooper, W.W. and Rhodes, E. (1978) Measuring the Efficiency of Decision-Making Units. European Journal of Operational Research, 2, 429-444.

[9] Majumder, S.K. (1994) Assessing Firms Capabilities Theory and Measurement-A Study of Indian Pharmaceutical-Industry. Economic and Political Weekly, 29, 8389.

[10] Banker, R.D., Charnes, A. and Cooper, W.W. (1984) Some Models for Estimating Technical and Scale Inefficiencies in Data Envelopment Analysis. Management Science, 30, 1078-1092. https://doi.org/10.1287/mnsc.30.9.1078

[11] Färe, R., Grosskopf, S., Yaisawarng, S.K. and Wang, Z. (1990) Productivity Growth in Illinois Electric Utilities. Resources and Energy, 12, 383-398.

[12] Färe, R., Grosskopf, S., Norris, M. and Wang, Z. (1994) Productivity Growth, Technical Progress and Efficiency Change in Industrialised Countries. The American Economic Review, 84, 66-83.

[13] Hjalmarsson, L. and Veiderpass, A. (1992) Productivity in Swedish Electricity Retail Distribution. Scandinavian Journal of Economics, 9, S193-S205. https://doi.org/10.2307/3440259

[14] Berg, S.A., Førsund, F. and Jansen, E. (1992) Malmquist Indices and Productivity Growth during the Deregulation of Norwegian Banking, 1980-89. Scandinavian Journal of Economics, 94, S211-S228. https://doi.org/10.2307/3440261

[15] Price, C.W. and Weyman-Jones, T. (1996) Malmquist Indices of Productivity Change in the UK Gas Industry before and after Privatization. Applied Economics, 28, 29-39. https://doi.org/10.1080/00036849600000004

[16] Caves, D., Christensen, L. and Diewert, W.E. (1982) The Economic Theory of Index Numbers and the Measurement of Input, Output, and Productivity. Econometrica, 50, 1393-1414. https://doi.org/10.2307/1913388

[17] Charnes, A., Cooper, W.W., Lewin, A.Y. and Seiford, L.M. (1993) Data Envelopment Analysis: Theory, Methodology and Applications. Kluwer Academic Publishers, Boston.

[18] Nishimizu, M. and Page, J. (1982) Total Factor Productivity Growth, Technological Progress and Technical Efficiency Changes. Economic Journal, 92, 920-936. https://doi.org/10.2307/2232675

[19] Friedman, L. and Sinuany-Stern, Z. (1998) Combining Ranking Scales and Selecting Variables in the Data Envelopment Analysis Context: The Case of Industrial Branches. Computers and Operations Research, 25, 781-791.

[20] Shammari, M. (1999) A Multi-Riteria Data Envelopment Analysis Model for Measuring the Productive Efficiency of Hospitals. International Journal of Operations \& Production Management, 19, 879-891. https://doi.org/10.1108/01443579910280205

[21] Ulucan, A. (2002) Data Envelopment Analysis Approach in Efficiency Measurement of 1 S0500 Companies: Evaluations Using Different Input Output Components and Different Returns to Scale, Ankara University. Journal of Political Science, 57, 
185-202.

[22] Zhu, J. (2000) Multi-Factor Performance Measure Model with an Application to Fortune 500 Companies. European Journal of Operational Research, 123, 105-124.

[23] Bayyurt, N. and Duzu, G. (2008) Performance Measurement of Turkish and Chinese Manufacturing Firms: A Comparative Analysis. Eurasian Journal of Business and Economics, 1, 71-83.

[24] Tahir, I.M. and Memon, M.A. (2012) Size and Operational Performance of Manufacturing Companies in Pakistan Using Data Envelopment Analysis. Journal of Information Engineering and Applications, 2, 39-49.

[25] Cusumano, M.A. (1988) Manufacturing Innovation: Lessons from the Japanese Auto Industry. Sloan Management Review, 30, 29-39.

[26] Friedlander, A.F., Winston, C. and Wang, K. (1982) Cost, Technology, and Productivity in the U.S. Automobile Industry. Bell Journal of Economics, 13, 1-20.

[27] Mazumdar, M. and Rajeev, M. (2009) A Comparative Analysis of Efficiency and Productivity of the Indian Pharmaceutical Firms: A Malmquist-Meta-Frontier Approach. The Institute for Social and Economic Change, Working Paper 223.

[28] Saranga, H. and Phani, B.V. (2009) Determinants of operational efficiencies in the Indian pharmaceutical industry. International Transactions in Operational Research, 16, 109-130. https://doi.org/10.1111/j.1475-3995.2009.00668.x

[29] Keramidou, I., Mimis, A. and Pappa, E. (2011) Estimating Technical and Scale Efficiency of Meat Products Industry: The Greek Case. Journal of Applied Sciences, 11, 971-979. https://doi.org/10.3923/jas.2011.971.979

[30] Sueyoshi, T. (1997) Measuring Efficiencies and Returns to Scale of Nippon Telegraph \& Telephone in Production and Cost Analyses. Management Science, 43, 779-796. https://doi.org/10.1287/mnsc.43.6.779

[31] Facanha, L.O. and Resende, M. (2004) Price Cap Regulation, Incentives and Quality: The Case of Brazilian Telecommunications. International Journal of Production Economics, 92, 133-144.

[32] Cooper, W.W., Park, K.S. and Yu, G. (2001) An Illustrative Application of IDEA (Imprecise Data Envelopment Analysis) to a Korean Mobile Telecommunication Company. Operations Research, 49, 807-820. https://doi.org/10.1287/opre.49.6.807.10022

[33] Uri, N.D. (2001) Technical Efficiency, Allocative Efficiency and the Impact of Incentive Regulation in Telecommunications in the United States. Structural Change and Economic Dynamics, 12, 59-73.

[34] Uri, N.D. (2001) The Effect of Incentive Regulation on Productive Efficiency in Telecommunications. Journal of Policy Modeling, 23, 825-846.

[35] Batra, G. and Tan, H. (2003) SME Technical Efficiency and Its Correlates: Cross National Evidence and Policy Implications. World Bank Institute Working Paper.

[36] Wu, H.L. (2005) A DEA Approach to understanding the Performance of Taiwan's Steel Industries 1970-1996. Asia Pacific Management Review, 10, 349-356.

[37] Din, M., Ghani, E. and Mahmood, T. (2007) Technical Efficiency of Pakistan's manufacturing Sector: A Stochastic Frontier and Data Envelopment Analysis. The Pakistan Development Review, 46, 1-18.

[38] Singh, S.P. (2007) Performance of Sugar Mills in Uttar Pradesh Ownership, Size and Location. Prajnan, Journal of Social and Management Sciences, 35, 333-359.

[39] Meenakumari, R. and Kamaraj, N. (2008) Measurement of Relative Efficiency of 
State Owned Electric Utilities in INDIA Using Data Envelopment Analysis. Modern Applied Science, 2, 61-71. https://doi.org/10.5539/mas.v2n5p61

[40] Caves, R. and Barton, D. (1990) Efficiency in US Manufacturing Industries. MIT Press, Cambridge, MA.

Submit or recommend next manuscript to SCIRP and we will provide best service for you:

Accepting pre-submission inquiries through Email, Facebook, LinkedIn, Twitter, etc. A wide selection of journals (inclusive of 9 subjects, more than 200 journals)

Providing 24-hour high-quality service

User-friendly online submission system

Fair and swift peer-review system

Efficient typesetting and proofreading procedure

Display of the result of downloads and visits, as well as the number of cited articles Maximum dissemination of your research work

Submit your manuscript at: http://papersubmission.scirp.org/

Or contact ajor@scirp.org 